\title{
Indonesian Monetary Regulation Regarding Chinese Electronic Payment in Indonesia
}

\author{
Claudia Mulyawan ; Emmy Latifah ${ }^{\star \star}$ \\ Faculty of Law, Universitas Sebelas Maret \\ ^claudiamulyawan@gmail.com

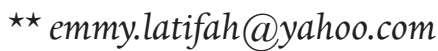

\begin{abstract}
This article aims to analyze and find the answer on how the regulation for transaction activities deals with electronic money by Chinese tourists in Indonesia, especially in Bali, as well as to analyze the effect on using WeChat Pay and Alipay payment in tourism sector. This legal research is using normative research method. It is concluded that Chinese electronic payment platform WeChat Pay and Alipay by Chinese tourists for doing payment transactions in Bali has not been explicitly regulated in Indonesia because those providers have not fulfilled any requirements and standards from Indonesian Central Bank (Bank Indonesia) and have not obtained any Indonesian legal status as a private company. Transactions using Chinese electronic also have impact for the country's foreign exchange reserves. Foreign exchange reserves is one of the important aspect in deciding the value of state budget (APBN) that is also influenced by foreign exchange reserves from tourism sector.
\end{abstract}

Keywords: electronic money; payment transaction; tourism; Indonesian monetary regulation.

\section{A. Introduction}

Tourism is one of the Indonesia's most reliable economic activities and one of the sources of Indonesia's foreign exchange reserves. 
Data from Indonesian Statistical Bureau (Badan Pusat Statistik/BPS) that has been released on $22^{\text {nd }}$ May 2018 shows that tourism is on the fourth rank position on Indonesia's foreign exchanges rate upon another 11 export commodities below oil and gas, coal, and crude palm oil. ${ }^{1}$ Foreign exchange rate from tourism sector in 2015 was US\$ 12,225.89 million, and has been increased from US \$10,054.15 million in 2013 and US\$11.166,13 million in $2014 .^{2}$ This huge amount of Indonesia's foreign exchange rate makes tourism as the most promising sector for Indonesia and can be reliable for Indonesian economic activities.

There are a lot of tourists that doing domestic trips in Indonesia, especially foreign tourists. Data from The Ministry of Tourism Indonesia shows that foreign tourists who are visiting Indonesia are about 1.158.162 people in January 2019, and during Januari until December 2018 foreign tourists that visiting Indonesia is about 15.806 .191 people. ${ }^{3}$ Those amount of foreign tourists shows that tourism is one of the most promising economic sector and also can be a potential business sector in Indonesia.

The top three of the most foreign tourists that visiting Indonesia are tourists from Malaysia, People's Republic of China, and Singapore. Foreign tourists from Malaysia on February 2019 is about 275.288 people, while foreign tourists from People's Republic of China is about 200.949 people and tourists from Singapore is about 147.948 people on February 2019. ${ }^{4}$ The most foreign tourists that has been visiting Indonesia from countries outside ASEAN countries are

1 Ranking Devisa Pariwisata terhadap 11 Ekspor Barang Terbesar Tahun 2011 2015. http:/ / 103.107.101.52/asset_admin/assets/uploads/media/old_all/ devisa2011-2015.pdf. Accessed on 29th April 2019.

2 Ibid.

3 Data Kunjungan Wisatawan Mancanegara Bulanan Tahun 2019 (Januari Tahun 2019). http: / / www.kemenpar.go.id/ post/ data-kunjungan-wisatawan-mancanegara-bulanan-tahun-2019-januari-tahun-2019. Accessed on 29th April 2019.

4 Jumlah Kunjungan Wisman Menurut Kebangsaan dan Bulan Kedatangan Tahun 2017 - 2019. https://www.bps.go.id/dynamictable/2018/07/30/1548/ jumlah-kunjungan-wisman-menurut-kebangsaan-dan-bulan-kedatangantahun-2017---2019.html. Accessed on 29th April 2019. 
tourists from People's Republic of China.

People's Republic of China has been evolving from the countries that using communism as their main ideology and economic system becoming one of the country with the most significant economic growth among the other emerging economic countries. The data from Bloomberg economic magazine shows that People's Republic of China is on the top rank from 20 countries that had been categorized as emerging economic countries above South Korea and Thailand. The Gross Domestic Product (GDP) growth of People's Republic of China from 2013 to 2017 is about $45.9 \%$ an inflation rate of $3 \%$ makes the country on the top list of the emerging economic countries rank. Indonesia is on the tenth position of this rank with the amount of the Gross Domestic Product (GDP) from 2013 to 2017 about $31.3 \%$ and inflation rate about $4.6 \% .^{5}$

Rapid economic growth in People's Republic of China causing a lot of Chinese people to do foreign tourism, especially in Indonesia. One of the tourism destinations that mostly visited by tourists from China is Bali Province that has been famous for the beautiful scenery and tourism object with a lot of activities to do. Foreign tourists from China that visited Bali based on the data from the Department of Tourism Official (Dinas Pariwisata Daerah) Bali Province from January until October 2018 is about 1.361 .512 people and from January to February 2019 is about 238.134 people. ${ }^{6}$ Tourists that are coming from China is on the first rank position for the most foreign tourists that come to visiting Bali, above tourists from Australia with 160.333 people and tourists from India with 57.760 people on January until February 2019.?

Capable facilities is needed in order to ease Chinese tourists while having their trip in Indonesia. One of the facilities that are most needed is the payment facilities that ease the tourists while they

5 The Top 20 Emerging Markets. https: / / www.bloomberg.com/news/photoessays/2013-01-31/the-top-20-emerging-markets. Accessed on 29th April 2019.

6 Statistik. http://www.disparda.baliprov.go.id/id/Statistik4. Accessed on 29th April 2019.

7 Ibid. 
are making transactions on their trip. One of the payment facilities that are mostly needed is through electronic payment platform or most widely known as e-money that has been widely used in modern society.

Electronic money in a form of electronic wallet that can be used throughout smartphone application and using QR Code as the media of payment processing is now a trend among technology and information companies to developing it. One of the pioneers for e-money payment in Indonesia is Go-Pay that is owned by PT. Aplikasi Karya Anak Bangsa (Go-Jek Indonesia) that was originally used as the payment platform for Go-Jek's services such as motorcycle taxi service 'Go-Jek' and online food delivery service 'Go-Food' and developing into an electronic wallet that can be used to do transactions in several shops. Beside Go-Pay, there is another online payment platform called 'LinkAja' developed by PT. Telekomunikas Selular or Telkomsel that can be used by smartphone.

China also has their own electronic payment called Alipay that is owned by e-commerce company Alibaba Group and WeChat Pay that is owned by technological company Tencent. Those online payment platforms has been expanding to Indonesia and can be used by Chinese tourists in Indonesia while having their trip. Those online payment platform can be used in several local minimarkets and hotels in Bali.

Based on the Bank Indonesia (Indonesian Central Bank) Bali Province Branch's observation, the number of shops that receive transactions through Chinese online money platform are about 608 shops that is widely spread in Bali Province. ${ }^{8}$ Among 90 percent of WeChat Pay and Alipay usage in Indonesia is in Bali Province and mostly used by tourists from China in Bali. Unfortunately, WeChat Pay and Alipay payment transactions in Indonesia has not obtained any permission from Bank Indonesia (Indonesia’s Central Bank) to run its operational activities. ${ }^{9}$

8 Ekspansi Mobile Payment Tiongkok. https://analisis.kontan.co.id/news/ekspansi-mobile-payment-tiongkok. Accessed on 8th May 2019.

9 Transaksi Turis China di Bali: WeChat Pay Untung, Bali Buntung. https: / / tirto. 
The usage of electronic payment platform from China in Indonesia that has been widely used in Bali Province makes Bank Indonesia as Indonesian Central Bank should make a new law regulation regarding the usage of foreign electronic payment in tourism activities. Peraturan Bank Indonesia (Indonesian Central Bank Regulation) No. 19/8/PBI/ 2017 about National Payment Gateway (Gerbang Pembayaran Nasional/GPN) has not specifically regulating about electronic payment in Indonesia especially about Alipay and WeChat Pay electronic payment platform as a new thing in Indonesian transaction platform.

This research will be about on how Indonesian government, especially Bank Indonesia (Indonesian Central Bank) should do as an institution that has the duty on controlling payment activities and regulating monetary transactions especially monetary transaction through electronic money that can causing a positive effect on Indonesian economic system. Otherwise, this research will also observing about the effect of the regulation regarding Chinese electronic payment platform on tourism sector in Bali.

This research is using normative legal research which is using literature review as the method to do the research. Type of data that is used in this research is secondary data including: primary legal sources such as law regulations about monetary and banking regulations especially about digital money; secondary legal sources including research articles that has been published in a scientific journals; and tertiary law sources from dictionary. ${ }^{10}$ Data collection method used by this research is literature study while data analysis method used in this research is legal interpretation method. ${ }^{11}$

id/transaksi-turis-cina-di-bali-wechat-pay-untung-bali-buntung-danN. Accessed on 8th May 2019.

10 Soerjono Soekanto and Sri Mamudji, Penelitian Hukum Normatif: Suatu Tinjauan Singkat, PT Rajagrafindo Persada, Depok, p. 29, 2015.

11 Soerjono Soekanto, Pengantar Penelitian Hukum. UI Press, Depok, p. 252, 2010. 


\section{B. Results and Discussions}

\section{Definitions on Electronic Money}

According to the publication that has been released by Bank of International Settlement (BIS) in October 1996, electronic money is product that has a store - value amount or prepaid that has some money stored in an electronic media that is owned by someone. Electronic money (e-money) is a payment media that can be used for multi purposed payment method. ${ }^{12}$

Another definition of electronic money is defined by European Central Bank as "an electronic store of monetary value on a technical device that may be widely used for making payments to undertakings other than the issuer without necessarily involving bank accounts in the transaction, but acting as a prepaid bearer instrument" 13 This definition means that electronic money is an electronic deposit in a technology device that can be used widely as the payment method.

Electronic money has the same characteristics and functions with the money that is usually used for cash transactions. Electronic money can be used on various payment instruments and also used for the small amount of transactions. Although transactions using electronic payment is usually not in a huge amount, the users of electronic money itself has to top up their own account through Automatic Teller Machine (ATM). ${ }^{14}$

Electronic money has the potential to give a positive effect for its users such as practical usage, convenience and privacy, lesser fee

12 Laila Ramadani, "Pengaruh Penggunaan Kartu Debit dan Uang Elektronik (E-Money) Terhadap Pengeluaran Konsumsi Mahasiswa”, Jurnal Ekonomi dan Studi Pembangunan. Vol 8(1), p. 1-8, March 2016.

13 Georgios Papadopoulos, Electronic Money and the Possibility of Cashless Society, available at SSRN: https://ssrn.com/abstract $=982781$ or http: / / dx.doi.org/10.2139/ssrn.982781, p. 1-22, February 2007.

14 Imaduddin Sahabat, dkk, "Electronics Payment Decisions of the Indonesian Urban Households: A Nested Logit Analysis of the Effects of Payment Characteristics", International Journal of Economics and Financial Issues, Vol. 7(5), p. 498-511, 2017. 
payment, potential new business, and transfer of financial activities on the internet. In the other side, there are some controversial issues linked to the usage of the electronic money itself such as tax and money laundering. Otherwise, the issues that has also arise is about the user's data privacy and the possibility of user's data leakage. ${ }^{15}$

Electronic money has the negative impact to macro-economic activities such as exchange currency volatility and the lesser guarantee of the real money. The lesser guarantee of the real money might be caused by a lot of electronic money that is widely used rather than the spread of the real money itself. The other negative impact that should be aware of is the security and consumer's right protection for the electronic money usage in case of the fraud and money loss. Electronic money itself can be used easily by another irresponsible party without the Personal Identification Number (PIN) that is usually used in transactions with debit card or signature as usually used in credit card transaction. ${ }^{16}$

\section{Alipay and WeChat Pay Concepts}

Alipay is one of the electronic payment platforms. Alipay's payment methods are using prepaid method or charging user's credit card or debit card account directly. Alipay can be used on P2P (Person to Person Payment) transaction, online transaction, and also for telephone bill, airplane ticket or train ticket, electric bill, and water bill payment. In the registration process, Alipay users should make their own Alipay account using their own phone number of e-mail address and then activated their debit card account for transferring some amount of money to their Alipay account. Alipay users must input the code that has been sent via SMS (Short Message Service) to their respective phone number while doing electronic transaction with the regu-

15 Krzysztov Woda, "Money Laundering Techniques with Electronic Payment Systems", Information \& Security. An International Journal, Vol. 18, p. 27-47, 2006.

16 Dwi Wulandari, dkk, "Analysis of the Use of Electronic Money in Efforts to Support the Less Cash Society", International Finance and Banking, Vol. 3(1), p. 1-10, 2016. 
lar payment method or using password for faster payment method. ${ }^{17}$

Similar to Alipay, WeChat Pay is also a payment application with mobile payment based that is released by instant messaging platform WeChat and also their own payment application called TenPay. Before using WeChat Pay application, users should fill in their own personal data such as credit card number, phone number, and special verification code. Payment process can be done by just using password. By this time, WeChat Pay has four payment methods such as payment using mobile phone number, App payment (payment method using mobile phone application), sweep payment (A bank account set up to operate so that at the end of each banking day all or a portion of the funds on deposit in the account are automatically transferred into another account $)^{18}$, and payment using credit card. ${ }^{19}$

\section{Electronic Money Regulation in Indonesia}

Electronic money usage in Indonesia as one of the payment methods has not been explicitly regulated in Indonesian legal system. Regulations regarding electronic money usage are only regulated in Indonesian Central Bank Regulation (Peraturan Bank Indonesia/PBI) No. 19/8/PBI/2017 about National Payment Gateway (Gerbang Pembayaran Nasional/GPN) and Indonesian Central Bank Regulation (Peraturan Bank Indonesia / PBI) No. 20 / 6/ PBI/ 2018 about electronic money. Although those two regulations has the similarities on regulating electronic money payment, but those two regulations has different regulation scope.

PBI No. 19/8/PBI/ 2017 about National Payment Gateway regulated about the procedures of secure payment methods. National Payment Gateway provider is divided into three categories: standard

17 Yue Liu, "Consumer Protection in Mobile Payments in China: A Critical Analysis of Alipay’s Service Agreements”, Computer Law \& Security Review, Vol. 31(5), October 2015, p. 679-688.

18 Glossary: Sweep Account. https://uk.practicallaw.thomsonreuters.com / 4-507-1504?transition Type $=$ Default $\&$ contextData $=(\mathrm{sc}$. Default $) \&$ firstPage $=$ true $\& b h c p=1$. Accessed on 12th July 2019.

19 Wei Xu, "The Study of WeChat Payment Users Willingness Factor", Journal of Service Science and Management, Vol. 10, p. 251-259, 2017. 
provider, switching provider, and services provider. Standard provider has a duty to ensure the interconnection and interoperability in making and organizing standards especially payment instrument standards, payment canal standards, and transactional services features standards. Switching provider has a duty to facilitating data forwarding in domestic transaction activities in order to create and maintaining interconnection and interoperability efficiently and securely. Services provider has a duty to providing interconnected payment access, regulating, and also ensure the capability on doing safe transactions. ${ }^{20}$

PBI No. 20/6/PBI/2018 about electronic money regulates the different matter and specifically regulates on electronic money itself. This regulation explains about the institution categories that can be qualified enough to provide electronic transaction and the requirements for banking companies or another companies to become electronic payment provider in Indonesia. ${ }^{21}$

Indonesian Central Bank (Bank Indonesia) is an organization that has the duty as legal person and serves as an independent state organization that cannot be intervened while doing its duty, including government intervention. Indonesian Central Bank (Bank Indonesia) itself is a legal subject that can be included in legal person subject. ${ }^{22}$ Indonesian Central Bank (Bank Indonesia) has a purpose to maintaining and stabilize rupiah currency. In order to achieve that purpose, Indonesian Central Bank (Bank Indonesia) has some duties to establishing and implementing monetary policy, regulating and maintaining the payment system, and also regulating and supervising banks. ${ }^{23}$

Although Indonesian Central Bank (Bank Indonesia) is a legal subject that is categorized as legal person and serves as Indonesia's independent state organization, but in international economic law

20 Explanation Part on Bank of Indonesia Decree Number 19/8/PBI/2017 on National Payment Gate.

21 Bank of Indonesia Decree Number 20/6/PBI/2018 on Electronic Money.

22 Article 4 Bank of Indonesia Act 23/ 1999.

23 Article 7-8 Bank of Indonesia Act 23/1999. 
a country's central bank is the representation of the country itself in imposing and implementing its economic policy and not as the regular legal person. ${ }^{24}$ So, Indonesian Central Bank (Bank Indonesia) as country's central bank has a right to imposing any payment and monetary policies.

According to Indonesian Central Bank Regulation (PBI) No 19/8/7/PBI/2017, WeChat Pay and Alipay can be categorized as service platform that should provide interconnected payment platform. In this regulation, Article $19-23$ have the regulations on the category by a payment provider to become a service provider in payment system. The requirements for a service provider to legally operated in Indonesia is regulated on Article 19 Clause 2: (1) Indonesian legal subject and in 'perseroan terbatas' (company) form; (2) has the capability to do its services function in Indonesian National Payment Gateway (GPN); (3) its shares are owned respectively by switching provider or conventional bank based on a BUKU 4 company which its stocks majority owned by Indonesian citizen and/or Indonesian legal person.

This regulation shows that WeChat Pay an Alipay should be in a form of Indonesian legal person company and its shares has to be owned by switching provider and BUKU 4 bank. Buku 4 bank requirements has been regulated in Indonesian Monetary Provider Authority Regulation (Peraturan Otoritas Jasa Keuangan) No 6/ POJK.03/2016 about company activities and office networking based on the core interests. Bank that can be categorized as BUKU 4 can do several financial activities such as collecting money and fund from public and funding any trade activities in Rupiah or any other foreign currencies and also capital shares in Indonesian and overseas financial institution.

WeChat Pay and Alipay status that have not obtained any legal status as a private company and their shares have not been owned by switching provider and BUKU 4 bank makes those payment platforms not having a legal status to be operating their business in Indo-

24 Matthias Herdegen, Principles of International Economic Journal, Oxford University, England, p. 26, 2013. 
nesia. The truth is those payment platforms have been used in Bali without any confirmation to Indonesian Central Bank (Bank Indonesia). Otherwise, those payment platforms are not provided by a private company that has obtained legal status in Indonesia as one of the requirements to operating their business in Indonesia.

Indonesian Central Bank Regulation (PBI) No. 20/6/PBI/2018 about electronic money Article 6 Clause 2 mentions that electronic payment provider that is not a banking institution should be a company that obtained a legal status. Article 7 mentions that the majority of the direction board of the non-banking institution should be located in Republic of Indonesia territory. Those two aspects is included in legality aspect and it also one of the requirements to providing electronic money payment that has been regulated in Article 13 of that regulation.

Legality aspect is one of the requirements that must be fulfilled by WeChat Pay and Alipay to providing digital payment process in several shops in Bali. This is also has an effect on the supervision from Indonesian Central Bank (Bank Indonesia) as the country's central bank. Legality aspect is also important to guarantee protection on the shops and Chinese tourists that using WeChat Pay and Alipay services when there is any problem with the transaction.

The currency that should be used in Indonesian electronic money transaction is Rupiah. Article 51 Indonesian Central Bank Regulation (PBI) about electronic money mentions that electronic money transaction in Indonesia must be in Rupiah currency. The real situation that happens in Bali is that transactions via WeChat Pay and Alipay in Indonesia are done with Chinese Renminbi/Yuan currency.

Although those regulations has regulated about the requirements for any banking institutions or non-financial institutions to provide any electronic payment platform in Indonesia, those regulations do not contain any administrative sanction in any of the clauses for those who are violating Indonesia's Central Bank (Bank Indonesia) policies on providing electronic payment services. Administrative sanction is needed in order to ensure the law enforcement that every institutions are obey to Indonesia's Central Bank regulations as 
the state representative and central bank in Indonesia. Administrative sanction can be in written warning form or operational ban if the institution has not obtained any permission from Bank Indonesia.

Bank Indonesia also has an obligation to regulate about whose person that can using Chinese electronic payment platform in Bali. Bank Indonesia can make such a limitation that Alipay and WeChat Pay users that can using the platforms for payment transactions in Indonesia are only for Chinese tourists. This should be done in order to protecting Indonesia's local electronic payment provider and also creating better business competition environment between those electronic payment provider in Indonesia.

Bank Indonesia can also make any regulation about the obligation for the currency in WeChat Pay and Alipay account to be converted from Chinese Renminbi/Yuan into Rupiah currency if they want to do electronic payment in Indonesia. This have to be done in order to make electronic money payment can be done easily and meet Bank Indonesia’s requirement for electronic money payment.

\section{The Effect of Chinese Electronic Money Usage on Tourism Sector in Bali Province}

Chinese electronic money usage in Indonesian tourism sector has an effect on Chinese tourist convenience when they are visiting Bali without bring a huge amount of cash money and bringing debit and credit card that are usually charge them with additional bank fee if they want to use it for transactions in several shops across Bali. Otherwise, the usage of WeChat Pay and Alipay is also ease payment transactions for Chinese tourists because the payment can be done through smartphone application by scanning available barcode in that shop.

But the usage of Chinese electronic money for some transactions in Bali has an effect on Indonesia's foreign exchange reserves. If there are many tourists that visiting a particular country, there is an increasing in a country's foreign exchange reserves and can also increasing the availability of foreign exchange value. In the other side, 
if there are many tourists that are tourists outflow from a particular country there will be a decreasing amount of foreign exchange reserves. ${ }^{25}$ Payment using WeChat Pay and Alipay in Bali with Chinese Renminbi/Yuan currency will be have an effect to Indonesia's foreign exchange reserve in tourism sector. Although the effect is not significantly affect the Indonesia's tourism foreign exchange reserve as a whole, but a huge number of Chinese tourists that are visiting Bali has an impact on tourism foreign exchange reserves especially in Bali Province. Foreign exchange reserves in tourism sector that is on the fourth rank in Indonesia's foreign exchange reserves rank has an effect on Indonesia's income from tourism sector.

\section{Conclusions}

Tourism sector is one of the Indonesia's most dependable sector because this is one of the Indonesia's economic sector that brings a lot of income for Indonesia and also positioned on fourth rank of Indonesia's top eleven foreign exchange reserves. A huge amount of foreign tourists that are visiting Indonesia, especially in Bali Province, makes tourism as one of the most promising sector for Indonesia. The most number of tourists from non ASEAN countries that are visiting Bali are tourists from People's Republic of China with the number of 200.949 people.

The usage of Chinese electronic payment platform WeChat Pay and Alipay by Chinese tourists for doing payment transactions in Bali has not been explicitly regulated in Indonesian legal regulation because those providers has not fulfill any requirements and standards from Indonesian Central Bank (Bank Indonesia) and has not obtained any Indonesian legal status as a private company. Although those platform ease Chinese tourists in doing payment transactions in Indonesia and only used by Chinese tourists, but those payment platforms cannot be used for transactions in Indonesia because those payment platforms have not meet Indonesian Central Bank require-

25 Muhammad Afdi Nizar, "Pengaruh Jumlah Turis dan Devisa Pariwisata terhadap Nilai Tukar Rupiah”, Jurnal Kepariwisataan Indonesia, Vol 7(2), p. 492-512, 2012. 
ments.

Transactions using Chinese electronic has also an impact for the country's foreign exchange reserves. Foreign exchange reserves is one of the important aspect in deciding the value of state budget (APBN) that is also influenced by foreign exchange reserves from tourism sector.

\section{Bibliography}

\section{Legal Documents}

Bank of Indonesia, Act No. 23/1999

, Decree Number 19/8/PBI/2017 on National Payment

Gate

, Decree Number 20/6/PBI/2018 on Electronic Money

\section{Books}

Adolf, Huala, 2005, Hukum Ekonomi Internasional: Suatu Pengantar, Jakarta: PT Rajagrafindo Persada.

Herdegen, Matthias, 2013, Principles of International Economic Journal, Inggris: Oxford University Press.

Liu, Yue, "Consumer Protection in Mobile Payments in China: A Critical Analysis of Alipay's Service Agreements”, Computer Law \& Security Review, Vol. 31(5), October 2015.

Nizar, Muhammad Afdi, "Pengaruh Jumlah Turis dan Devisa Pariwisata terhadap Nilai Tukar Rupiah”, Jurnal Kepariwisataan Indonesia, Vol 7(2), 2012.

Papadopoulos, Georgios, 2017, "Electronic Money and the Possibility of Cashless Society”, Available at SSRN: https://ssrn.com/ abstract $=982781$ or http: / / dx.doi.org/10.2139/ssrn.982781.

Ramadani, Laila, 2016, "Pengaruh Penggunaan Kartu Debit dan Uang Elektronik (E-Money) Terhadap Pengeluaran Konsumsi Mahasiswa", Jurnal Ekonomi dan Studi Pembangunan, Vol 8(1).

Sahabat, Imaduddin, dkk, 2017, "Electronics Payment Decisions of the Indonesian Urban Households: A Nested Logit Analysis of the Effects of Payment Characteristics", International Journal of 
Economics and Financial Issues, Vol. 7(5).

Soekanto, Soerjono, 2010, Pengantar Penelitian Hukum, Depok: UI Press.

Soekanto, Soerjono dan Sri Mamudji, 2015, Penelitian Hukum Normatif: Suatu Tinjauan Singkat, Depok: PT Rajagrafindo Persada. Woda, Krzysztov, 2006, "Money Laundering Techniques with Electronic Payment Systems", Information \& Security. An International Journal, Vol. 18.

Wulandari, Dwi, dkk, 2016, "Analysis of the Use of Electronic Money in Efforts to Support the Less Cash Society", International Finance and Banking, Vol 3(1).

$\mathrm{Xu}$, Wei, 2017, "The Study of WeChat Payment Users Willingness Factor", Journal of Service Science and Management, Vol. 10.

\section{Websites}

Data Kunjungan Wisatawan Mancanegara Bulanan Tahun 2019 (Januari Tahun 2019). http://www.kemenpar.go.id/post/data-kunjungan-wisatawan-mancanegara-bulanan-tahun-2019-januari-tahun-2019. (Accessed on 29 ${ }^{\text {th }}$ April 2019).

Ekspansi Mobile Payment Tiongkok. https://analisis.kontan.co.id/ news/ekspansi-mobile-payment-tiongkok. (Accessed on $8^{\text {th }}$ May 2019).

Glossary: Sweep Account. https://uk.practicallaw.thomsonreuters.

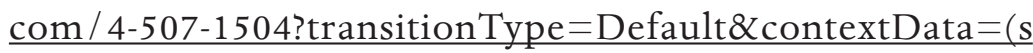
c.Default) \&firstPage $=$ true $\&$ bhcp $=1 . \quad$ (Accessed on $12^{\text {th }}$ July 2019).

Jumlah Kunjungan Wisman Menurut Kebangsaan dan Bulan Kedatangan Tahun 2017 - 2019. https://www.bps.go.id/ dynamictable/2018/07/30/1548/jumlah-kunjungan-wismanmenurut-kebangsaan-dan-bulan-kedatangan-tahun-2017---2019. html. (Accessed on $29^{\text {th }}$ April 2019).

Ranking Devisa Pariwisata terhadap 11 Ekspor Barang Terbesar Tahun 2011 - 2015. http://103.107.101.52/asset admin/assets/uploads/media/old all/devisa2011-2015.pdf. (Accessed on $29^{\text {th }}$ April 2019). 
Statistik. http://www.disparda.baliprov.go.id/id/Statistik4. (Accessed on $29^{\text {th }}$ April 2019).

The Top 20 Emerging Markets. https:/ / www.bloomberg.com/news/ photo-essays/2013-01-31/the-top-20-emerging-markets. (Accessed on $29^{\text {th }}$ April 2019).

Transaksi Turis China di Bali: WeChat Pay Untung, Bali Buntung. https: / / tirto.id/transaksi-turis-cina-di-bali-wechat-pay-untungbali-buntung-danN. (Accessed on $8^{\text {th }}$ May 2019). 